\title{
Applying Binnendifferenzierung in Reading for German-Learners Practice and Its Challenge
}

\author{
Dwi Imroatu Julaikah \\ Universitas Negeri Surabaya \\ Surabaya, Indonesia \\ dwijulaikah@unesa.ac.id
}

\begin{abstract}
Reading is an important skill in German language teaching and learning. Based on preliminary observations, it is shown that some of German learners have difficulties to understand texts. This condition leads to a lot of problems. One of the problems raises is the capability of German learners which are vary each others. So, it is important to use different strategies in learning and teaching process in reading class. This paper aims to know the implementation and problematic from the strategy of Binnendifferenzierung in reading learning for German beginner learners in Universitas Negeri Surabaya. The writer found the indications, that Germanlearners have low capability in understanding reading texts. These Problems are caused by; (1) minimum amount of vocabularies, (2) low motivation for reading, (3) gaps in abilities between learners. This paper is based on qualitative descriptive research. This research was done in reading class for German learners in Universitas Negeri Surabaya, They were in the forth study semester. This paper will describe the implementation and the problematic of using this Binnenifferenzierung strategy. Results showed that the reading comprehension ability of low group learners increased after the implementation of the strategy. Problematic in the implementation of Binnendifferenzierung found is that it needs a long time for preparation in applying the strategy. The heterogeneity of learners' abilities take a long time for the researcher or lecturer to prepare the assignment instrument for the text.
\end{abstract}

Keywords- Binnendifferenzierung ; reading, implementation and problematic; low capability

\section{INTRODUCTION}

Reading is a complex activity based on theory stated by Nurhadi [1]. In reading activities, the reader needs to understand a lot of things, especially orthography, grammatical understanding, and vocabularies. All of the factors are needed to be considered in order to understand the meaning of text.

Reading also has meaning decoding $\mathrm{X}$ comprehension. It means that reading results from an ability to decode the print and to comprehend the language that is thus unlocked [2].

Besides, there are a lot of activities when we are reading texts. One of them is moving our eyes across lines of text. The readers may occasionally use a finger to keep our place, turn pages in books or scroll text on computer screens. The readers may also use speech articulation to read aloud or subvocalize them as they read. Beyond this, little psychomotor activity is involved in reading, and most of this activity is not specifically taught [3].

In German class at University, the learners must have different level of reading competencies. Starting from basic reader or literal level (A-1 standard) until creative reader (B2 standard). At the literal level, the basic facts are understood. For example, knowing that the lady's name is Miss Chow; she lives in an apartment on the 10th floor; her neighbors are noisy; she has complained to the landlord before. These information are explicitly stated within the text. At the creative level, the readers can take information or ideas from what have been read and develop new ideas from them. The creative level stimulates the reader to new and original thinking [4].

Experiencing as a lecturer in teaching German reading skills, the writer sees that; it is not easy for beginner learners to understand text or doing reading activities. The observations and pre-studies were taken during teaching Germany. The writer has found some indications. There are (1) minimum amount of vocabularies, (2) low motivation for reading, (3) gaps in abilities between learners. At about $70 \%$ of students in German Languange Education Study Program in Universitas Negeri Surabaya are not familiar with the German language when they were studying in high school. The rest of learners know German as extracurricular and as the preferred foreign language. Moreover, many learners do not take a language class while they were in high school. The difference of early input or knowledge creates a disturbing in the learning 
process in the classroom. It caused differences in the level of understanding of reading. Therefore, there is a need for the implementation specific or various strategies, or teachers need created workshop-like settings in which children had much choice in what they read [5]

One of strategies to solve the problem above is Binnendifferenzierung. People also call this strategy as innere differenzierung. Binnendifferenzierung is a learning strategy which can be used in learning and teaching process with students in various level of background knwledge input. It can include differentiation of assignment, theme, forms of teaching and so on [6].

Finally, this paper discussed about (1) How is the implementation of Binnendifferenzierung in learning students reading, (2) What are the problems of using Binnendifferenzierung strategy in reading learning in germany teaching?

\section{BINNENDIFFERENZIERUNG}

The concept of Binnendifferenzierung strategy has been done by a lot of writer or researcher. Dra. Hafdarani, M.Pd at the Department of German University of Education (UPI) Bandung. She taught reading skills with Binnendifferenzierung strategy. She implemented Classroom Action Research on the strategy. She also used the same strategy in doing research of listening skills as the classroom action research.

The concept of Binnendifferenzierung was firstly developed in the German around the year of 1970. The term of Binnendifferenzierung or commonly called innere Differenzierung is a differentiation strategy of learning process. Teachers organize different learning process among students. The term of differences are explained as difference in intelligence, interest, learning motivation and initial knowledge. Schwerdtfeger (2001: 105) states that

"Unter innerer Differenzierung versteht man die Möglichkeit, den Lernprozess für verschiedene Lernende unterschiedlich zu gestalten.[6]

It means that by differences, strategies allow the learner to have opportunity to learn with a lot of ways. The use of Binnendifferenzierung needs various characteristics of learners. Binnendifferenzierung can also be applied individually or in groups. The selection of this form requires a lot of things, for example the classroom conditions. It is applied the same either individual or group implementation. The implementation of the strategy in groups is suggested in a way that learning in groups has a lot of advantages. According to Eiling and Frey, learning in groups has a lot of advantages, such as the learner can solve individual problem [7]. Vorteile der Gruppenarbeit: der Menschen hilft: konkrette Probleme zu lösen.
Basically, the difference in Binnendifferenzierung is implemented according to language comprehension level. In teaching and learning process of reading comprehension, the difference can be created in terms of the form of assignment, the differences of media used, and the basic content of learning (class or group). All of those items are made on differences among learners. The concept of differentiation of learning with Binnendifferenzierung can be described as follows:

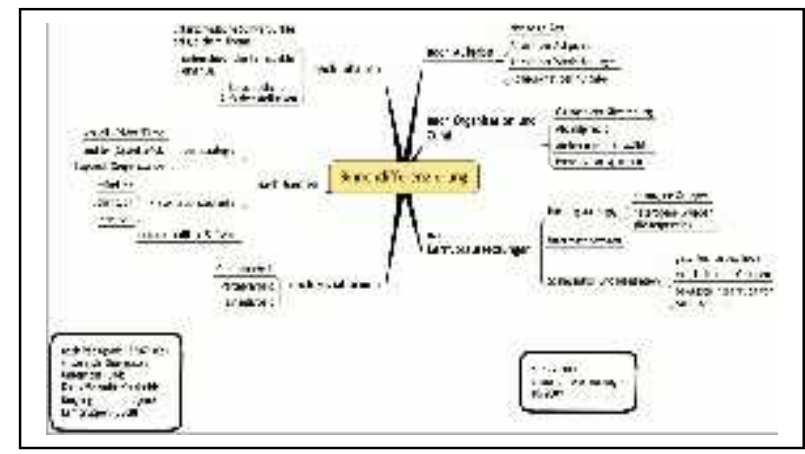

Fig.1 the scheme of Binnendifferenzierung concept retrieved from http://lehrerfortbildung-bw.de/di download date 20/1/2012.

There are many variations and differences in the process of reading learning through Binnendifferenziefierung strategy.

Those variations are, (1) Differenzierung nach Aufgaben (Different types of training), (2) Differenzierung nach Themenbereichen (Different type of themes), (3) Differenzierung nach Sozialformen (Differentiation of teaching form), (4) Differenzierung nach Leistungsniveau (Differentiation based on level of understanding), (5) Differenzierung nach Lernwegan (differencrs of learners' type) [6]. Furthermore, Schwerdftfeger give steps using this strategy as follows:

(1) Differentiate the exercise types. Learning with different exercise type requires the students to choose the materials and to read and to underline sentence and find the meaning of the sentence.

(2) Selecting text-cuts- and scrambles. The learners are asked to read and to organize the text

(3) Selecting text - cutting and missing last paragraph of the text -.The learners are asked to read and to complete the last paragraph.

(4) Selecting text. The learners are asked to read and to answer questions with $5 \mathrm{~W}+1 \mathrm{H}$ (what, who, was, when why and how).

\section{METHOD}

This research employed qualitative descriptive study. The data was collected through observation of reading activities which are designed based on Schwerdtfger and Frey's Binnendifferenzierung 
strategy. The implementations of the strategy refers to the Binnendifferenzierung strategy of Schwerdfrger and which have steps answering - submitting - checking and answering questions. [6] [7]. This research emplyoed 3 type strategies as follow;

(1) Differenzierung nach Aufgaben (differentiation type of exercise),

In this step, researcher prepared the instrument in the form of homogeneous reading for standard B1-1 learners. The exercises are different. Types of task variations were as follows;

a. The same text - different types of assignments, it included underlining the important sentences and searching for the meaning and idea of the subject, the second of was answering the questions based on the texts.

b. The same text - different form of teaching process, the first was individual, and the second was in pairs or groups

c. Different texts. The teacher give 3 texts and different forms of exercises. For example making resume, writing content of the text.

\section{RESULTS AND DISCUSSION}

The participant of this research were forth semester students of German Language Education Study Program Universitas Negeri Surabaya. At this level, the participants in this class should have international standard of German (B1 standart). This standard of language proficiency refers internasional standart, GeR (Gemeinsamer Europaeischer Referenzrahmen). But the reality is not so. German language skills of the learners still heterogeneous. Most learners showed and indicated the low capability.

The data in this study was taken thoroughly from 21 students. But data descriptions focused on students with low ability. The data collection was done by involving all students of a class in the teaching learning process. The results analysis focused on 8 students with low ability. The classification of students who have low ability for reading based on the indicator that the students have not passed the Zids exam. It should be noted that Zids is a standardization test that must be taken by all students of German language in Indonesia. This test is as one of the requirements that must be taken to describe the competence of German Languange learners in Indonesia. For the German language study program in Universitas Negeri Surabaya, this exam is also used as a prerequisite to be able to take the final thesis exam in addition to other conditions such as passing Test of English Proficiency (TEP) with a score of 425 .

The first implementation of Binnendifferenzierung was done by giving the same text- with different type of exercises. There are four different types of assignments required. They are (a) highlighting the important sentences and searching for the meanings and ideas of the text (b) answering the questions assignment and making a summary, (c) writing content of the text, 4) Comparing the text with title 'Cultural locks of love in Indonesia and Germany. The text used is about love. It is adapted to the same way in the class but the assignment is different, it is to work individually. The assignment is as follows;

(1) Text Liebesschloesser, highlighting the main idea.

(2) Text Liebesschloesser, making a summary

(3) Text Liebesschloesser, writing content of the text,

(4) Text Liebesschloesser, comparing the culture of love-with text. Students were required to compare the culture of love-with the lock of love.

The four types of assignments had different difficulty levels. The assignment for underlining was the simplest and easiest assignment. Then, the learners had to make a summary. At last. The learners were required to compare the text "the culture of love" with "the lock of love."

These four types of assignments referred to learning objectives, understanding of the text well. Although learners' learning experiences were different from others, in the the end of learning process, the four forms of assignment were discussed together. The achievement of learning objectives was deeper and details understanding the text by discussing. The different forms of assignment were intended to accommodate the differences and heterogeneity of learners' abilities in the class.

For this implementation, researcher gave an explanation of the theme and the difficulty level of each assignment. By explanation, the learners knew the level of difficulty of the material, so that students could measure the ability and choose the form of the appropriate assignment they would take.

Based on the observation done by the researcher, students chose the correct type of assignment. This could be seen from the type of assignment of the simplest degree of difficulty chosen by the low-ability students, and the students who have higher ability levels choose the higher difficulty level. In general, this process gave positive impact in learning process, and it triggered to a better achievement of learning objectives, especially students groups.

The second implementation was conducted following these steps. The text is the same, but the teaching process was different. Learners worked individually, partner or in groups. Learners used the same text but the social form is different. The text entitled "Yasmin Deutschland 1987/1998." It was written by Regie Hawk Bohan. This text talks about love of a girl named Yasmin, aged 17 years. She was from Turk, who was recently lived in Hamburg Altona. Yasmin fell in love with a young man named Judo. He was a student with differentt background. He was not a Turkish. On the other hand, Yasmin's father did not agree with their relationship. Initially, this text talked 
about love with different culture. The story was also filmed in Turkish cultural perspective. It was also colored by conflict between generations. This implementation by using the text; using the same text, but the social form is different. This form of partner was more likely to be selected by the learner. Learners thought that working in a partner helped them to discuss about ideas. Learners found easier to understand the text during reading activities with their partners. They could contribute in sharing information and ideas. Group variation was composed not only from low groups. There was a tendency that the members of low ability learners cooperated with the learner who have higher ability. Variation of students' abilities, in this case, provided advantage because the higher learnes could be helpful in maintaining the discussion.

The third implementation of

Binnendifferenzierung was done by giving different texts. The first text entitled '42 Prozent der Vermieter leben allein. This text contains diagrams and texts that tell about the percentage of tendencies from the German. About 42 percent of these tenants live alone. The number is getting smaller for the tenants who live with three, four or five people together. This type of assignment in the the second text involved question, such as "Why these singles can cause environmental problems?." The first text entitled 'die Grosste Liebe' (Great Love). There were different texts and all of that text talked about three different couples. The first text talked about a couple, namely Ernst Kostner, 77 and Maya Stiener, 73. The second text talked about a true love from Pia Fischer, 40 years and 28-year-old Cornellius Horseman. It described how their love grew in an atmosphere of complementarity. Cornellius did not see any age difference between them. The third text was telling about Paula Gomes 35 and Ana Gomes 32. This text talked about the meeting between two people who came from different countries, they are Paulo came from Sao Paulo and Anna Derived from England who worked at the same office, as a company's marketing. These three texts had the same type of assignment, with the following question types. There are (1) read the three texts from magazine. What do you think? (2) How or where did you meet? (3) How do the situation of the couple? (4) What plans do the couples have?

After the iimplementation, the writer found some of problems. The problems identified in the preparations. The preparations; needed a lot of time, especially preparing for making instrument of assignments. The biggest problem was the different types of assignment required a long time to make them. The lack of resources was also one of the problems occured. Besides, at the same time, there are others problems occured; the freedom for doing assignment make students or learners confused and misguided the type of assignments. Choosing partners also gave a contribution to the decision of choosing assignment types. Another problem is the limited time in implementation of Binnendifferenzierung

\section{V.CONCLUSION}

After the implementation of various Binnendifferenzierung, there are some conclusions that can be drawn. The learners who have lower ability choose the simplest form of assignment, namely underline. Although they prefer to choose the easiest assignment, the learner can improve their understanding of the texts given. They are able understand a detailed reading by underlining the text. Moreover, they have better understanding by discussing with other groups who did different assignments. Finally, the researcher concludes that the learners have better undertsanding in reading procces by implementing this strategy namely "Binnendifferenzierung"

\section{REFERENCES}

[1] Nurhadi, Bagaimana Meningkatkan Keterampilan Membaca. Bandung: Sinar Baru Algensindo, 2005.

[2] N. Flynn and R. Stainthorp, The Learning and Teaching of Reading and Writing. England: Whurr Publishers Limited (a subsidiary of John Wiley \&Sons Ltd), 2006.

[3] S. Mark, Conceptual Foundations of Teaching Reading. New York-London: The Guilford Press, 2014.

[4] P. Westwood, Reading And Learning Difficulties: Approaches To Teaching And Assessment. Camberwell : Accer Press, 2001.

[5] E. McIntyre, Reading Instruction for Diverse Classrooms. Research-Based, Culturally Responsive Practice. New York: The Guilford Press.

[6] I. C. Schwerdtfger, "Gruppenarbeit und innere Differenzierung," 2001.

[7] A.F. Eiling, and K. Frey, Angewälte Methoden der Didaktik. Zürich : Hochschulverlag, 2010. 